\title{
Effects of Nursing on Growth and Development of Small Bowel Mucosa in Newborn Piglets
}

\author{
MARTIN H. ULSHEN, JAMES G. LECCE, ALAN D. STILES, AND LASCELLES E. LYN-COOK \\ Department of Pediatries. Core Center for Gastrointestinal Biology and Discase. University of North Caroline \\ Sihool of Medicine, Chapel Hill. North Carolina 27599-7220 [M.H.U., A.D.S., L.E.L.-C.) and Department of \\ Animal Sciences. Core Center for Gastrointestinal Biology and Disease. North Carolina State University, \\ Raleigh, North Carolina 27695 [J.G.L./
}

\begin{abstract}
Trophic factors in natural milk are potential mediators of the rapid growth of intestine in neonates. To determine whether nursing stimulates growth and development of small bowel mucosa, litters of piglets were divided into suckled and artificially reared groups at birth. The latter animals were raised in an automated feeding device (Autosow) with an artificial diet simulating the nutritional composition of sow milk. At 2, 8, and $15 \mathrm{~d}$ of age, animals were killed and $10-\mathrm{cm}$ segments of jejunum, mid-bowel, and ileum were removed. Mucosal homogenates were prepared for enzyme assay and measurement of mucosal mass. Mean body weight, total length of bowel, and circumference of bowel segments did not differ between the two feeding groups at any age studied. As anticipated, mean mucosal ornithine decarboxylase activity decreased $(p<0.001)$ and measurements of mucosal mass increased $(p<0.001)$ with age; however, mean values for each of these measures were never greater in the nursed animals in comparison to the artificially reared group in any segment at any age. In addition, levels of disaccharidase activity did not correlate with the feeding regimen. To investigate the possibility that unanticipated growth factors in the artificial diet might have accounted for the apparent lack of trophic effect of nursing compared to artificial rearing, we evaluated the effects of this diet and of sow colostrum on ${ }^{3} \mathrm{H}$-thymidine incorporation in Swiss $3 \mathrm{T3}$ cells in vitro. Colostrum, but not artificial diet, stimulated greater incorporation of ${ }^{3} \mathrm{H}$-thymidine than culture medium alone $(p<0.005)$. The mitogenic activity of colostrum was not inhibited by the addition of neutralizing antibody against epidermal growth factor or IGF-I. In conclusion, the effect of nursing on growth and development of the small bowel mucosa in the piglet does not differ from that of rearing with an artificial diet, despite the finding that porcine colostrum has greater growth-promoting activity than artificial diet in vitro. Neither epidermal growth factor nor IGF-I alone in colostrum appears to be required for this mitogenic effect. (Pediatr Res 30: 337-341, 1991)
\end{abstract}

\section{Abbreviations}

EGF, epidermal growth factor

FBS, fetal bovine serum

MEM, Eagle's minimum essential medium

ODC, ornithine decarboxylase

TGF, transforming growth factor

Received August 28, 1990; accepted June 5, 1991.

Correspondence: Martin H.. Ulshen, M.D., Department of Pediatrics, CB\# 7220 , Burnett-Womack Bldg. University of North Carolina, Chapel Hill, NC 27599 7220.

Supported by a grant from the Center for Gastrointestinal Biology and Disease. University of North Carolina, Chapel Hill. NC (NIH DK34987). A.D.S. is a recipient of NIH Grant No. R29HL38902.
Oral or enteral feeding is necessary for maintenance of normal small bowel mucosal mass and digestive enzyme activity in animals $(1,2)$. Intraluminal administration of nutrient is also required for the initiation of adaptive growth of small bowel $(e . g$ after jejunectomy) $(3,4)$. Enteral nutrients may promote mucosal growth directly or may act indirectly by stimulating secretion of trophic factors $(5,6)$. Peptide factors that have been considered potential growth regulators for the small bowel mucosa include EGF, enteroglucagon, TGF, IGF-I, and insulin (7-11).

Small bowel mucosa undergoes rapid growth during the neonatal period (12). Natural milk, the primary diet of neonates, contains both nutrients and growth factors (e.g. EGF, TGF, insulin, IGF, and lactoferrin) (13-20). Therefore, nursing might be expected to stimulate growth and development of the mucosa of the small intestine beyond the effects of ingested nutrients alone. However, previous studies of the effects of nursing and of natural milk on the small bowel have produced contradictory results (21-25). Furthermore, administration of one of these growth factors, EGF, to neonatal rats in artificial diet has been associated with growth of small intestine only when provided at concentrations much greater than those occurring naturally in rodent milk $(26,27)$.

In the present studies, we evaluated the effects of nursing, in comparison to artificial feeding, on growth and development of small bowel mucosa in newborn piglets during the first $15 \mathrm{~d}$ of age. Inasmuch as the manner of feeding (e.g. frequency and volume) may influence mucosal growth, an automated, artificialrearing device (Autosow) was used to provide feedings to newborn piglets in a physiologic fashion. To evaluate whether the artificial diet, which was similar to sow milk in nutrient composition and caloric content, might have contained factors with growth stimulatory or inhibitory properties, we performed additional in vitro studies exposing murine Swiss $3 \mathrm{~T} 3$ cells to artificial diet or porcine colostrum and measuring ${ }^{3} \mathrm{H}$-thymidine incorporation into DNA.

\section{MATERIALS AND METHODS}

Effects of nursing and of artificial rearing on small bowel. These studies were approved by the Institutional Animal Care and Use Committee. Crossbred sows from the closed North Carolina State University herd were brought into a fumigated, intensive-care, farrowing facility $5 \mathrm{~d}$ before their parturition date. Sows were thoroughly bathed and sanitized before entry and daily thereafter. At the time of farrowing, one half of the piglets studied were caught and removed to an isolated room containing an automatic feeding device (Autosow); the other piglets were allowed to remain with the sow and suckle ad libitum (28). Piglets for these studies came from a total of 13 litters.

The Autosow is a self-contained, computerized device for 
feeding and maintaining piglets in individual cages. Piglets in the Autosow were offered an artificial diet that consisted of nonfat cow milk solids, fat, vitamins, and minerals. This diet contained $20 \%$ solids, composed of $30 \%$ protein, $40 \%$ lactose, and $20 \%$ fat by weight (29). The diet was similar to sow milk with regard to caloric density as well as the ratio of protein to fat and carbohydrate calories. Each piglet received $12.5 \mathrm{~mL}$ of diet $/ \mathrm{kg}$ body weight/h. In previous studies, piglets raised in the Autosow with this diet gained weight at a rate comparable to that of nursed animals (29).

Animals were allowed to feed until the time of death and were killed by stunning and rapid exsanguination. Artificially reared and nursed piglets were killed alternately in litter pairs at 2,8 , and $15 \mathrm{~d}$ of age. Small bowel was excised rapidly and the length measured under uniform tension of a $40 \mathrm{~g}$ weight. Ten-cm segments of jejunum, mid-bowel, and ileum were removed (50 $60 \mathrm{~cm}$ distal to the ligament of Treitz, $5 \mathrm{~cm}$ on either side of mid-bowel, and $50-60 \mathrm{~cm}$ proximal to the ileocecal valve, respectively). The segments were irrigated with iced $0.9 \% \mathrm{NaCl}$, $\mathrm{pH} 7.4$, immediately frozen on dry ice, and stored at $-20^{\circ} \mathrm{C}$ for less than $1 \mathrm{wk}$.

Bowel segments were opened longitudinally on iced glass plates. Measurements of bowel circumference were made at both margins and the middle of the segment and expressed as the mean for each segment. Mucosal scrapings were collected using glass slides and homogenized with a Teflon pestle in $10 \mathrm{vol}$ of iced $0.1 \mathrm{M} \mathrm{NaPO}_{4}$ buffer, $\mathrm{pH}$ 7.2. ODC activity was measured as described by Luk and Baylin (30). An $80-\mu \mathrm{L}$ aliquot of the 1:10 homogenate was incubated for $1 \mathrm{~h}$ at $37^{\circ} \mathrm{C}$ with $0.5 \mu \mathrm{Ci}$ of $\mathrm{D}, \mathrm{L}-\left[1-{ }^{14} \mathrm{C}\right]$ ornithine (Research Products International, Mount Prospect, IL) in an Eppendorf tube within a scintillation vial containing $50 \mu \mathrm{L}$ of hyamine hydroxide. One-half $\mathrm{mL}$ of $0.2 \mathrm{M}$ perchloric acid was then added to each tube and incubated at $37^{\circ} \mathrm{C}$ for an additional hour. The tubes were removed from the scintillation vials without disturbing the hyamine hydroxide; 10 $\mathrm{mL}$ of scintillation cocktail was added to each vial. Disintegrations per minute were determined in a liquid scintillation counter, and ODC sp act was expressed as the quantity of ${ }^{14} \mathrm{CO}_{2}$ released per mg mucosal protein per $h$.

Measurement of DNA content was performed using a fluorescent dye microassay technique (31). In brief, a $20-\mu \mathrm{L}$ sample of the 1:10 mucosal homogenate was added to $0.2 \mu \mathrm{g}$ fluorescent dye (Hoechst 33258; Polysciences Inc., Warrington, PA) in $2 \mathrm{~mL}$ $10 \mathrm{mM}$ Tris buffer, $\mathrm{pH} 7.4$, containing $0.1 \mathrm{M} \mathrm{NaCl}$ and $1 \mathrm{mM}$ EDTA. The concentration of DNA was read directly from a TKO 100 mini-fluorometer (Hoefer Scientific Instruments, San Francisco, CA) calibrated with highly purified calf thymus DNA $(100 \mu \mathrm{g} / \mathrm{mL}$; Sigma Chemical Co., St Louis, MO). Protein and disaccharidase assays were performed by modifications of the methods of Lowry and Dahlqvist, respectively, as previously described (32).

All assays were completed in duplicate. Results are expressed as mean $\pm \mathrm{SEM}$. Statistical comparisons in each age were performed with the paired $t$ test and among age groups with analysis of variance. For the latter groups, statistical differences were confirmed by the Scheffé method at the 0.05 level.

Mitogenic effects of artificial diet and of porcine colostrum in vitro. Colostrum was collected from sows during farrowing and immediately stored at $-20^{\circ} \mathrm{C}$. Representative samples of artificial diet were stored in a similar fashion. The mitogenic activities of the artificial diet and porcine colostrum were assessed with murine Swiss 3T3 cells, a well-characterized cell line used to study the regulation of cell proliferation (33). Swiss 3T3 cells, serum and culture medium were obtained from the Lineberger Cancer Research Center, University of North Carolina, Chapel Hill, NC. The Swiss 3T3 cells were grown in 24-well $\left(2 \mathrm{~cm}^{2} /\right.$ well) tissue culture plates (Costar, Cambridge, MA) with Dulbecco's modified Eagle's medium with penicillin $(100 \mathrm{U} / \mathrm{mL})$, streptomycin $(100 \mu \mathrm{g} / \mathrm{mL})$, and $10 \%$ FBS. Confluent cultures were washed with MEM and maintained overnight in serum-free
MEM. The culture medium was then replaced with MEM alone (control) or MEM with: 1) 10\% FBS, 2) $10 \%$ porcine colostrum, 3) $10 \%$ artificial diet, 4) $10 \%$ porcine colostrum $+10 \%$ FBS or 6) $10 \%$ artificial diet $+10 \%$ FBS. In each of the studies, $1 \mu \mathrm{Ci}$ ${ }^{3} \mathrm{H}$-thymidine (Amersham, Arlington Heights, IL) was added to each well. After $72 \mathrm{~h}$ of incubation, the cells were removed from the plate by trypsinization, cellular DNA precipitated with 0.4 $M$ perchloric acid in methanol, and radioactivity in the pellet determined in a liquid scintillation counter. Cell counts were stable or increased through the assay period.

In additional studies, polyclonal antibody to human EGF (a gift from Dr. E. O'Keefe, University of North Carolina, Chapel Hill, NC) and MAb to human IGF-I (SM 1.2, a gift from Dr. J. J. VanWyk, University of North Carolina, Chapel Hill, NC) were incubated individually at a dilution of 1:200 with $10 \%$ porcine colostrum and with MEM. Mitogenic activity was evaluated as described above. At a dilution of 1:50 000, the anti-EGF antiserum binds $50 \%$ of the $\mathrm{mEGF}$ in a $1-\mathrm{ng} / \mathrm{mL}$ solution (34). In a bioassay system using Balb-C 3T3 cells incubated with IGF-I ( 20 $\mathrm{ng} / \mathrm{mL}$ ), the IGF-I MAb inhibits ${ }^{3} \mathrm{H}$-thymidine incorporation into DNA to $50 \%$ of maximum at a dilution of $1: 100000$ and to $80 \%$ at a dilution of $1: 1000(35)$.

All studies were performed in quadruplicate. Statistical analysis of the data was performed using analysis of variance and Tukey's method of multiple comparisons.

\section{RESULTS}

Effects of mursing and of artificial rearing on small bowel. Mean body weight did not differ between the nursed and artificially fed groups of animals at any age studied (Table 1). Mean length of small bowel (ligament of Treitz to ileocecal valve) and mean circumference of each region of bowel (jejunum, midbowel, and ileum) also did not differ between the two feeding groups at each of the ages studied.

Mucosal mass of the small bowel, represented by mean DNA content of the mucosa per $\mathrm{cm}$ bowel length (Fig. 1), increased progressively between 2 and $15 \mathrm{~d}$ of age in both feeding groups in each of the regions of bowel studied $(p<0.001$, mid-bowel not shown). Patterns of increase of mucosal wet weight and protein content with age were similar to that of DNA content and, therefore, are not shown. For each of the measurements of mucosal mass, values from nursed animals did not differ significantly from those of the artificially reared piglets in any region at any of the ages studied.

Mean mucosal ODC sp act in the jejunum was elevated early in the neonatal period in both of the feeding groups (either 2 or $8 \mathrm{~d}$ versus $15 \mathrm{~d}$ of age, $p<0.001$, Fig. 2). However, mean ODC activity in the nursed animals was never greater than the mean level in the artificially fed group in any region of bowel at any of the ages studied (Fig. 2, mid-bowel not shown). Mean ODC sp act was greater in the artificially reared animals only in the midbowel and ileum at $15 \mathrm{~d},(p<0.025$ and $p<0.002$, respectively).

Sucrase sp act was negligible at 2 and $8 \mathrm{~d}$ of age in all animals. At $15 \mathrm{~d}$ of age, sucrase $\mathrm{sp}$ act was measurable only in jejunum and mid-bowel; mean sp act and total activity per $\mathrm{cm}$ of bowel length did not differ between feeding groups in these regions of bowel. Mean lactase sp act and total activity per $\mathrm{cm}$ of bowel length did not differ among the three age groups and did not differ between feeding groups in any region at any of the ages studied.

Mitogenic effects of artificial diet and of porcine colostrum in vitro. The incorporation of ${ }^{3} \mathrm{H}$-thymidine into DNA of Swiss $3 \mathrm{~T} 3$ cells exposed to various media is shown in Figure 3. Medium (MEM) containing 10\% FBS, $10 \%$ porcine colostrum, 10\% FBS $+10 \%$ porcine colostrum or $10 \%$ FBS $+10 \%$ artificial diet each stimulated greater incorporation of ${ }^{3} \mathrm{H}$-thymidine than MEM alone $(p<0.005)$. In contrast, the $\mathrm{dpm} /$ well did not differ significantly for medium with $10 \%$ artificial diet compared to MEM alone. Therefore, porcine colostrum, but not artificial diet, 
Table 1. Effects of artificial rearing (Autosow) and of nursing on mean body weight, small bowel length, and small bowel circumference in piglets*

\begin{tabular}{|c|c|c|c|c|c|c|c|}
\hline \multirow{3}{*}{$\begin{array}{l}\text { Age } \\
\text { (d) }\end{array}$} & \multirow[b]{3}{*}{ Group } & \multirow[b]{3}{*}{$n$} & \multirow[b]{3}{*}{ Body wt $(\mathrm{kg})$} & \multicolumn{4}{|c|}{ Bowel } \\
\hline & & & & \multirow[b]{2}{*}{ Length $(\mathrm{cm})$} & \multicolumn{3}{|c|}{ Circumference $(\mathrm{mm} \times 10)$} \\
\hline & & & & & Jej & Mid & Ilcum \\
\hline \multirow[t]{2}{*}{2} & Autosow & 6 & $1.50 \pm 0.12$ & $443 \pm 29$ & $68 \pm 4$ & $68 \pm 2$ & $57 \pm 2$ \\
\hline & Nursed & 6 & $1.68 \pm 0.11$ & $421 \pm 23$ & $68 \pm 8$ & $60 \pm 5$ & $53 \pm 3$ \\
\hline \multirow[t]{2}{*}{8} & Autosow & 12 & $2.26 \pm 0.11$ & $499 \pm 11$ & $90 \pm 5$ & $76 \pm 7$ & $65 \pm 6$ \\
\hline & Nursed & 12 & $2.51 \pm 0.11$ & $553 \pm 14$ & $87 \pm 6$ & $75 \pm 5$ & $65 \pm 4$ \\
\hline \multirow[t]{2}{*}{15} & Autosow & 6 & $3.25 \pm 0.09$ & $649 \pm 15$ & $87 \pm 3$ & $72 \pm 3$ & $76 \pm 6$ \\
\hline & Nursed & 6 & $3.90 \pm 0.36$ & $692 \pm 30$ & $87 \pm 6$ & $82 \pm 6$ & $83 \pm 6$ \\
\hline
\end{tabular}

* Values shown are mean \pm SEM. No significant differences are noted for any of the measurements comparing Autosow to nursed animals at each of the ages studied. $n$ represents the number of animals per group. Jej, jejunum; Mid, mid-bowel.

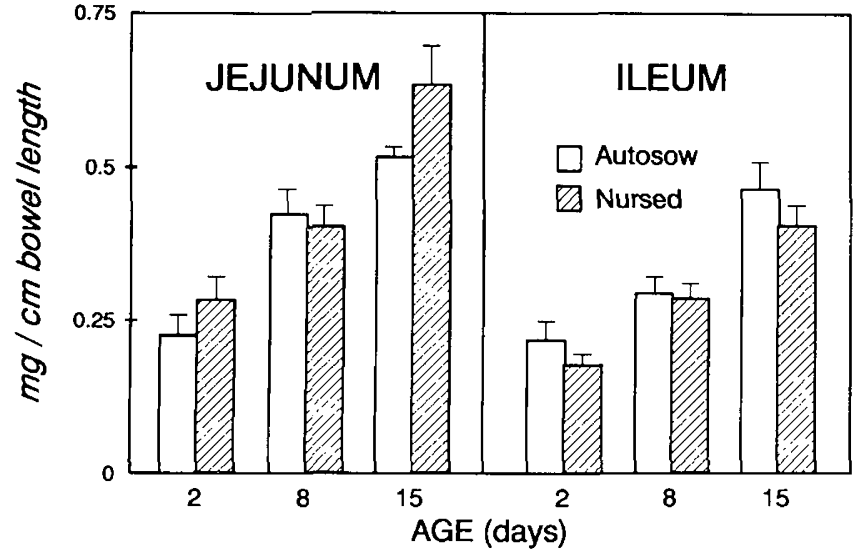

Fig. 1. Mean DNA content of small bowel mucosa in artificially reared (Autosow) vs nursed animals at 2, 8, and $15 \mathrm{~d}$ of age. Values do not differ significantly between the two feeding groups.

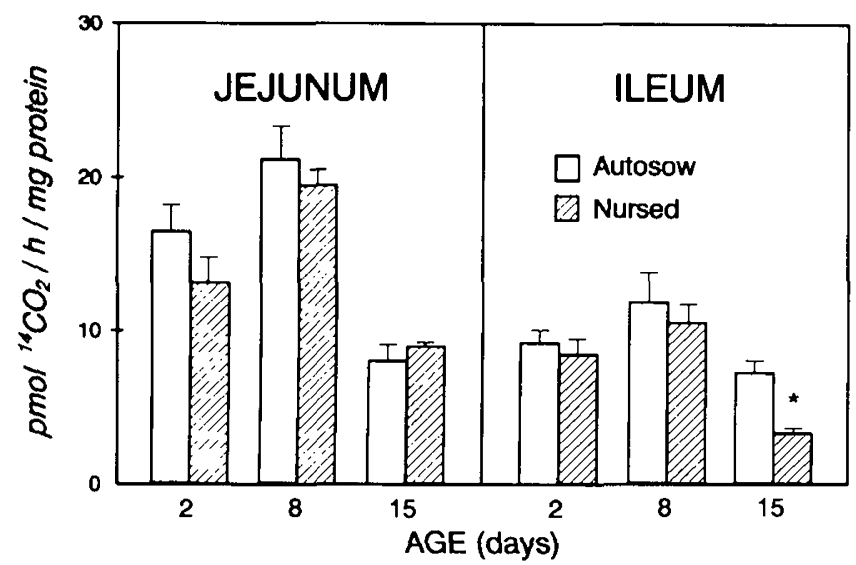

Fig. 2. Mean ODC activity of small bowel mucosa in artificially reared (Autosow) vs nursed animals at 2, 8, and $15 \mathrm{~d}$ of age (expressed as pmol ${ }^{14} \mathrm{CO}_{2}$ released from D,L- $\left[1-{ }^{14} \mathrm{C}\right]$ ornithine per h per mg of mucosal protein). ${ }^{*}, p<0.002$; no other statistically significant difference between feeding groups is shown.

increased DNA synthesis to the range observed with $10 \%$ FBS. No additive increase was observed when FBS and porcine colostrum were combined, and no apparent growth inhibitory effect was demonstrated when artificial diet was added with FBS. No inhibition of ${ }^{3} \mathrm{H}$-thymidine incorporation into DNA was observed with the addition of either anti-IGF-I or anti-EGF antibody to $10 \%$ porcine colostrum.

\section{DISCUSSION}

Natural milk contains a number of growth factors that have the potential to be regulators of growth and maturity of the small

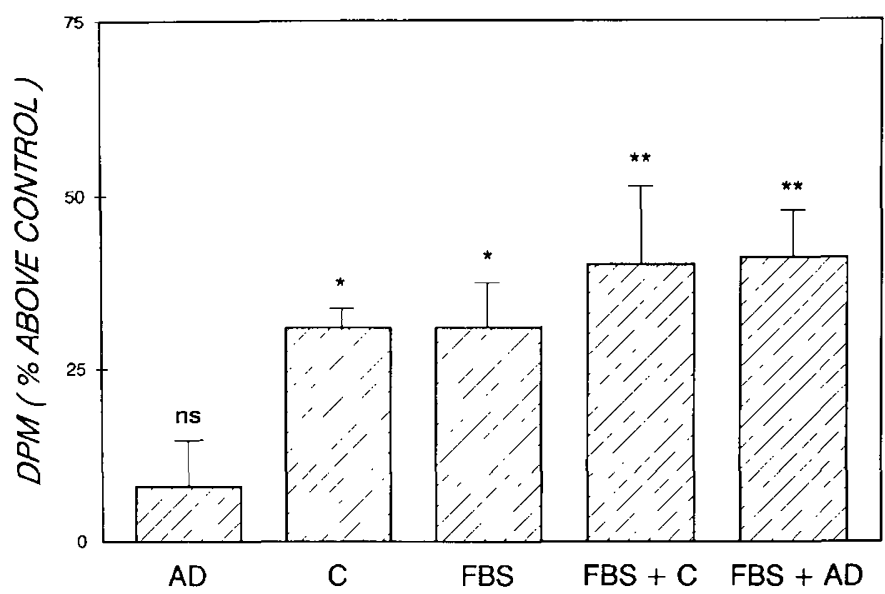

Fig. 3. Incorporation of ${ }^{3} \mathrm{H}$-thymidine into Swiss $3 \mathrm{~T} 3$ cells in vitro is expressed as the percentage above the mean control value (MEM alone), with the addition of 1$) 10 \%$ artificial diet $(A D), 2) 10 \%$ porcine colostrum (C), 3) $10 \% \mathrm{FBS}, 4) 10 \% \mathrm{FBS}+10 \%$ colostrum $(F B S+C)$, or 5) $10 \%$ FBS $+10 \%$ artificial diet $(F B S+A D) .{ }^{*}, p<0.005 ; * *, p<0.001: n s$ represents no significant difference from control values.

bowel mucosa in the neonate (7-11,13-20). In addition, suckling activity, in itself, may promote bowel development (e.g. by stimulating secretion of gastrointestinal fluids containing growth factors such as EGF). In an effort to evaluate the hypothesis that nursing stimulates small bowel growth, we compared the effects of nursing with those of artificial feeding on growth and development of the mucosa of the small bowel in newborn piglets during the first $15 \mathrm{~d}$ of life. We found that nursing, in comparison to artificial feeding, did not promote greater small bowel mucosal wet weight, DNA content, protein content, or length or circumference of the bowel.

ODC is an enzyme that contributes to the process of DNA synthesis; increased activity often serves as marker of stimulation of cell proliferation $(8,30)$. A transient rise in mucosal ODC activity is seen early in neonatal maturation of the small bowel in rodents and is similar to the transient rise occurring during the initiation of adaptive growth of small intestine in adult animals $(30,36)$. Alterations in mucosal disaccharidase activities also occur during bowel development in neonatal rats; near the time of weaning, lactase activity decreases while sucrase activity increases (37). In the present studies, development of ODC and disaccharidase activities behaved as anticipated; mean mucosal ODC activity decreased while mean mucosal sucrase activity increased late in the suckling period (36). Nursing did not appear to stimulate more rapid development of the small bowel mucosa than artificial feeding, inasmuch as the levels of enzyme activity did not correlate with the method of feeding. ODC activity was greater in mid-bowel and ileum of artificially reared animals at $15 \mathrm{~d}$ of age. The explanation for this observation is unknown. 
In an early effort to study the effects of nursing on small bowel in piglets, Widdowson et al. (38) found that suckling during the first $24 \mathrm{~h}$ of life led to growth of the mucosa of the small intestine, which did not occur in piglets fed water alone. However, this observation probably resulted from atrophy of small bowel mucosa in the starved animals; it has been shown subsequently that the weight of the small intestine of artificially reared rat pups varies with caloric intake (21). The findings of more recent reports have been inconsistent; nursing has been associated with small bowel mucosal mass greater, less, or equivalent to that of artificially fed animals $(21-25)$. A number of methodologic factors may have influenced the results of previous studies, including evaluation only at $24 \mathrm{~h}$ of life, use of formula nutritionally dissimilar to natural milk, and nonphysiologic administration of the artificial diet (such as forced feedings).

In the present studies, animals were reared artificially in the Autosow to simulate the normal pattern of frequent feeding in suckled piglets. Diet was offered at hourly intervals and the animals fed voluntarily. The volume offered and nutritional composition of the artificial diet was similar to the milk intake of suckled piglets. The animals that were allowed to continue to nurse remained in litters of reduced size. Therefore, any tendency for nursing to promote growth of the small bowel mucosa should have been accentuated by the increased milk supply available to the suckled animals (21). Precautions to maintain a herd free of enteric pathogens make it unlikely that mucosal damage from infectious enteritis influenced the results of these studies. Had enteric infection been a factor in these studies, the outcome would have favored preservation of the mucosa in the nursing animals, because piglets normally receive protective maternal antibody from colostrum during the first $2 \mathrm{~d}$ of life (39). It has been suggested that colostrum may have a greater trophic effect than mature milk (40); in this study, suckling piglets were nursed from birth and, therefore, were not deprived of normal exposure to colostrum.

Porcine colostrum, like the milks of a number of other species including man, contains high levels of a number of growth factors (EGF, IGF-I, insulin, and other growth factor(s) not yet identified) $(15,17-19)$. The concentrations of these growth factors decrease 10 -fold by about 1 wk postpartum, paralleling a similar drop in total protein concentration in natural milk. A basic premise in the interpretation of the present study is that the cowmilk-based, artificial formula did not contain growth factors as well, which might have promoted mucosal growth and, thereby, obscured any specific trophic effect of colostrum. To evaluate this possibility, we compared the mitogenic activity of the artificial diet with that of porcine colostrum samples, using an in vitro assay performed with Swiss 3T3 cells. Colostrum, but not artificial diet, stimulated greater DNA synthesis than culture medium alone, equivalent to the effect of FBS.

Both EGF and IGF-I have been shown previously to be mitogens in cell culture, including 3T3 and intestinally derived cells $(35,41-43)$, and these peptides may have paracrine trophic effects in the small intestine $(8,44,45)$. However, in the present in vitro studies, the lack of inhibition of mitogenic activity of porcine colostrum after addition of antibody against either peptide alone suggests that neither growth factor was individually responsible for this action.

In conclusion, the effect of nursing on growth and development of the small bowel mucosa in the piglet does not differ from that of rearing with an artificial diet, despite the finding that porcine colostrum has greater growth-promoting activity than artificial diet in vitro. Neither EGF nor IGF-I alone appears to be required in colostrum for this mitogenic effect. It seems likely that multiple factors contribute to the promotion of growth and development of the small bowel mucosa in the neonate. Therefore, in healthy newborn animals with customary nutrient intake, the trophic activity of natural milk does not appear necessary for normal progression of growth and maturation of small bowel mucosa. One can speculate that ingested growth factors might have a greater role during conditions of inadequate nutrient intake or recovery from enteritis.

\section{REFERENCES}

1. McManus JP. Isselbacher KJ 1970 Effect of fasting versus feeding on the rat small intestine: morphological, biochemical, and functional differences. Gastroenterology 59:214-221

2. Levine GM, Deren JJ. Steiger E, Zinno R 1974 Role of oral intake in maintenance of gut mass and disaccharide (sic) activity. Gastroenterology 67:975-982

3. Levine GM, Deren JJ, Yezdimir E 1976 Small-bowel resection: oral intake is the stimulus for hyperplasia. Dig Dis 21:542-546

4. Feldman EJ, Dowling RH, McNaughton J, Peters TJ 1976 Effects of oral versus intravenous nutrition on intestinal adaptation after small bowel resection in the dog. Gastroenterology 70:712-719

5. Dworkin LD, Levin GD, Farber NJ, Spector MH 1976 Small intestinal mass of the rat is partially determined by indirect effects of intraluminal nutrition. Gastroenterology 71:626-630

6. Spector MH, Levine GM, Deren JJ 1977 Direct and indirect effects of dextrose and amino acids on gut mass. Gastroenterology 72:706-710

7. Buchan AMJ, Griffiths CJ, Morris JF, Polak JM 1985 Enteroglucagon cell hyperfunction in rat small intestine after gut resection. Gastroenterology 88:8-12

8. Ulshen MH, Lyn-Cook LE, Raasch RH 1986 Effects of intraluminal epidermal growth factor on mucosal proliferation in the small intestine of adult rats. Gastroenterology 91:1134-1140

9. Shulman RJ 1990 Oral insulin increases small intestinal mass and disaccharides activity in the newborn miniature pig. Pediatr Res 28:171-175

10. Barmard JA, Beauchamp RD, Coffey RJ, Moses HL 1989 Regulation of intestinal epithelial cell growth by transforming growth factor type $\beta$. Proc Natl Acad Sci USA 86:1578-1582

11. Termanini B, Nardi RV, Finan TM, Parikh I, Korman LY 1990 Insulinlike growth factor I receptors in rabbit gastrointestinal tract: characterization and autoradiographic localization. Gastroenterology 99:51-60

12. Klein RM. McKenzie JC 1983 The role of renewal in the ontogeny of the intestine. I. Cell proliferation patterns in adult, fetal and neonatal intestine. J Pediatr Gastroenterol Nutr 2:10-43

13. Carpenter $G 1980$ Epidermal growth factor is a major growth-promoting agent in human milk. Science 210:198-199

14. Zwiebel JA, Bano M, Nexo E, Salomon DS, Kidwell WR 1986 Partial purification of transforming growth factors from human milk. Cancer Res 46:933939

15. Jaeger LA, Lamar CH, Bottoms GD, Cline TR 1987 Growth-stimulating substances in porcine milk. Am J Vet Res 48:1531-1533

16. Baxter RC, Zaltsman Z, Turtle JR 1984 Immunoreactive somatomedin-C/ insulin-like growth factor $\mathrm{I}$ and its binding protein in human milk. J Clin Endocrinol Metab 58:955-959

17. Simmen FA, Simmen RCM, Reinhart G 1988 Maternal and neonatal somatomedin C/insulin-like growth factor-I (IGF-I) and IGF binding proteins during early lactation in the pig. Dev Biol 130:16-27

18. Tan TJ, Schober DA, Simmen FA 1990 Fibroblast mitogens in swine milk include an epidermal growth factor-related peptide. Regul Pept 27:61-74

19. Westrom BR, Ekman R, Svendsen L, Svendsen J, Karlsson BW 1987 Levels of immunoreactive insulin, neurotensin, and bombesin in porcine colostrum and milk. J Pediatr Gastroenterol Nutr 6:460-465

20. Nichols BL. McKee KS, Henry JF, Putman M 1987 Human lactoferrin stimulates thymidine incorporation into DNA of rat crypt cells. Pediatr Res 21:563-567

21. Yeh KY 1983 Small intestine of artificially reared rat pups: effect of caloric intake and dietary composition on growth and disaccharidase activities. J Nutr 113:1496-1502

22. Heird WC, Schwarz SM, Hansen IH 1984 Colostrum-induced enteric mucosal growth in beagle puppies. Pediatr Res 18:512-515

23. Tonkiss J, Smart JL, Acuestad NS, Edmond J 1985 Type of milk substitute influences growth of the gastrointestinal tract in artificially reared rat pups. J Pediatr Gastroenterol Nutr 4:818-825

24. Thompson JF, Singh M, Wang Y, Zucker C, Heird WC 1986 Developmental differences in the effect of natural feeding on early enteric mucosal growth of guinea pigs. J Pediatr Gastroenterol Nutr 5:643-647

25. Weaver LT, Lucas A 1987 Upper intestinal mucosal proliferation in the newborn guinea pig: effect of composition of milk feeds. Pediatr Res 22:675678

26. Berseth CL 1987 Enhancement of intestinal growth in neonatal rats by epidermal growth factor in milk. Am J Physiol 253:G662-G665

27. Pollack PF, Goda T, Colony PC, Edmond J, Thornburg W, Korc M, Koldovsky O 1987 Effects of enterally fed epidermal growth factor on the small and large intestine of the suckling rat. Regul Pept 17:121-132

28. Lecce JG 1969 Rearing colostrum-free pigs in an automatic feeding device. J Anim Sci 28:27-33

29. Lecce JG, Coalson JA 1976 Diets for rearing colostrum-free piglets with an automatic feeding device. J Anim Sci 42:622-629

30. Luk GD, Baylin SB 1983 Polyamines and intestinal growth: increased polyamine biosynthesis after jejunectomy. Am J Physiol 245:G656-G660

31. Labarca C. Paigen K 1980 A simple, rapid, and sensitive DNA assay procedure. Anal Biochem 102:344-352

32. Ulshen MH, Herbst CA 1985 Effect of proximal transposition of the ileum on 
mucosal growth and enzyme activity in orally nourished rats. Am $\mathrm{J}$ Clin Nutr 42:805-814

33. Herschman HR 1987 Isolation of mitogen-specific non-proliferative varian cell lines. In: Barnes D. Sirbasker D (eds) Methods in Enzymology, Vol. 147 Academic Press. Orlando, FL. pp 355-369

34. O'Kecfe E, Bennetı V 1980 Use of immunoglobulin-loaded protein A-bearing staphylococci as a primary solid phase immunoadsorbent in radioimmunoassay. J Biol Chem 255:561-568

35. Russell WE, Van Wyk JJ. Pledger WJ 1984 Inhibition of the mitogenic effects of plasma by monoclonal antibody to somatomedin C. Proc Natl Acad Sci USA 81:2389-2392

36. Luk GD, Marton LJ, Baylin SB 1980 Ornithine decarboxylase is important in intestinal mucosal maturation and recovery from injury in rats. Science 210:195-198

37. Doell RG, Kretchmer N 1964 Intestinal invertase: precocious development of activity after injection of hydrocortisone. Science 143:42-44

38. Widdowson EM, Colombo VE, Artavanis CA 1976 Changes in the organs of pigs in response to feeding for the first $24 \mathrm{~h}$ after birth. II. The digestive tract. Biol Neonate 28:272-281
39. Lecce JG 1966 Absorption of macromolecules by neonatal intestine. Biol Neonate 9:50-61

40. Berseth CL, Lichtenberger LM, Moriss FH 1983 Comparison of the gastrointestinal growth-promoting effects of rat colostrum and maturc milk in newborn rats in vivo. Am J Clin Nutr 37:52-60

41. Feldman EJ Aures D Grossman MI 1978 Epidermal growth factor stimulates ornithine decarboxylase activity in the digestive tract of mouse. Proc Soc Exp Biol Med 159:400-402

42. Carpenter G. Cohen S 1979 Epidermal growth factor. Annu Rev Biochem 48:193-296

43. Duncan MD, Harmon JW, Korman LY, Bass BL 1990 Insulin and insulinlike growth factors enhance the proliferative effect of EGF on cultured human intestinal epithelial cells. Gastroenterology 98:A410(abstr)

44. Selub SE, Lund PK. Jin C, Fuller CR, Ulshen MH 1991 Effect of intraluminal EGF infusion on jejunal and ileal expression of JGF-mRNA in adult rats. Gastroenterology 100A:546(abstr)

45. Zimmermann E, Metz C, Ulshen MH, Selub SE, Smith E, Lund PK 1991 IGF-I and IGF-I precursor immunoreactivity in IGF-I transgenic mice. Gastroenterology 100:A678(abstr) 